\title{
Thermally oxidised sunflower-seed oil increases liver and serum peroxidation and modifies lipoprotein composition in rats
}

\author{
Carmen Garrido-Polonio ${ }^{1}$, M. Carmen García-Linares ${ }^{2}$, M. Trinidad García-Arias ${ }^{2}$, Sara López-Varela ${ }^{1}$, \\ M. Camino García-Fernández ${ }^{2}$, Antonius H. M. Terpstra ${ }^{3}$ and Francisco J. Sánchez-Muniz ${ }^{1}$ * \\ ${ }^{1}$ Departamento de Nutrición y Bromatología I (Nutrición), Facultad de Farmacia, Universidad Complutense de Madrid, \\ E-28040 Madrid, Spain \\ ${ }^{2}$ Instituto de Ciencia y Tecnología de los Alimentos, Universidad de León, León, Spain \\ ${ }^{3}$ Department of Laboratory Animal Science, Faculty of Veterinary Medicine, Utrecht University, Utrecht, The Netherlands
}

(Received 23 September 2003 - Revised 15 March 2004 - Accepted 19 March 2004)

Peroxidation of LDL and other lipoproteins is thought to play a central role in atherogenesis. Dietary thermally oxidised oils may increase atherogenic risk in consumers by increasing their oxidative status. The present paper compares the effects of two diets containing unused sunflower-seed oil (US) or sunflower-seed oil repeatedly used in frying (FS) (both $15 \mathrm{~g} / 100 \mathrm{~g}$ diet) on weight gain, food efficiency ratio, serum lipid levels and lipoprotein composition, and the content of thiobarbituric acid-reactive substances (TBARS) in the liver, serum, and lipoproteins in growing Wistar rats. After sixty potato fryings the FS contained $27.7 \mathrm{~g}$ polar material $/ 100 \mathrm{~g}$ oil and $16.6 \mathrm{~g}$ oligomers $/ 100 \mathrm{~g}$ oil. The FS-fed rats had a significantly lower weight gain and food efficiency ratio. Liver-TBARS increased due to the consumption of the highly altered oil and showed a significant linear relationship (all $r>0.68 ; P<0.002$ ) with the ingestion of thermally oxidised compounds. Serum-, VLDL-, LDL- and HDL-TBARS were significantly higher in the FS-fed rats (all $P<0 \cdot 001)$. Concentrations of serum total and non-esterified cholesterol and phospholipids were significantly higher in the FS-fed rats $(P<0.05, P<0.05$, and $P<0.001$, respectively). Serum triacylglycerol concentrations did not vary between the two dietary groups. Total and esterified cholesterol and phospholipid levels increased significantly in the HDL fraction $(P<0.05, P<0.05$, and $P<0.001$, respectively) of the FS-fed rats. HDL-cholesterol and HDL-phospholipids were significantly correlated with liver-TBARS $(r>0.747 ; P<0.0001)$, VLDL-TBARS $(r>0.642 ; P<0.003)$, LDL-TBARS $(r>0.475 ; P<0.04)$, and HDL-TBARS $(r>0.787 ; P<0.0001)$. The data suggest that the rat increases HDL as a protecting mechanism against the peroxidative stress induced by the consumption of a diet containing the thermally oxidised oil.

Deep-fat frying: Serum and lipoprotein peroxidation: Serum and lipoprotein lipids: Liver peroxidation

Diets of North Americans and inhabitants of the European Union countries contain substantial quantities of unsaturated fat that have been subjected to various degrees of processing and heat treatment. In addition, the majority of fast foods fried in oil contain oxidised lipids (Frankel et al. 1984) and the amount of oxidised lipids significantly increases when frying is performed following a slow or null replenishment with unused oil (Romero et al. 2000; Bastida \& SánchezMuniz, 2002). Romero et al. (2000) found that frozen precooked food in sunflower-seed oil also contains a relatively high content of altered fatty acids. Pancreatic lipase hydrolyses oxidised triacylglycerols in vitro (Sánchez-Muniz et al. 2000) and in vivo (Sánchez-Muniz et al. 1999), and the altered compounds are actively absorbed (Sánchez-Muniz et al. 1999).

Thus, diet may be the source of oxidised lipoproteins found in the intestinal lymph of rodents (Stapräns et al. 1993a). A direct relationship between the levels of oxidised lipids in the diet and the amount of oxidised lipids in the mesenteric lymph chylomicrons has been observed (Stapräns et al. 1993a,b). This finding suggests that, in rats, dietary oxidised lipids are absorbed by the small intestine, packaged in chylomicrons and transported to the bloodstream. Furthermore, these studies (Stapräns et al. $1993 a, b$ ) have shown that the metabolism of oxidised chylomicrons is similar to that of normal chylomicrons; a substantial proportion of oxidised lipids is delivered to the liver, where the lipids can be repackaged and secreted into VLDL. In a previous study, we found that liver-thiobarbituric acid-reactive substances (TBARS) were related to dietary fat alteration, suggesting that the liver actively takes up oxidised lipoprotein components (SánchezMuniz et al. 1998). Izaki et al. (1984) reported that liverTBARS were increased significantly in rats receiving four levels of thermally oxidised rapeseed oils in comparison with their counterparts fed fresh oil.

\footnotetext{
Abbreviations: FS, sunflower-seed oil repeatedly used in frying; Me-FA, fatty acid methyl esters; TBARS, thiobarbituric acid-reactive substances; US, unused sunflower-seed oil.

* Corresponding author: Professor Dr Francisco J. Sánchez-Muniz, fax + 3491 3941732, email dhtcgl@unileon.es
} 
The effect of heated oils on plasma lipids has been previously reviewed (Sánchez-Muniz \& Cuesta, 1998). However, information on the effect of the consumption of oils frequently used for frying on lipoprotein lipid and lipoprotein peroxidation is limited (Stapräns et al. $1993 a, b)$. Because of the increased consumption of food fried in oils rich in PUFA, the present study aimed to assess the effect of consuming a diet containing an abused sunflower-seed oil used repeatedly for frying (FS) on (i) acceptability and growth in young rats; (ii) liver size and liver-TBARS concentration; (iii) plasma lipids and lipid composition and TBARS concentration of VLDL, LDL and HDL.

\section{Materials and methods}

\section{Animals and diets}

The study was approved by the Spanish Science and Technology Advisory Committee (Comisión Asesora de Ciencia y Tecnología; CICYT) and by an ethics committee of the Facultad de Farmacia of the Universidad Complutense de Madrid (Spain). Rats were handled according to the Guide for the Care and Use of Laboratory Animals (National Research Council, 1985).

Eighteen growing male Wistar rats weighing approximately $65 \mathrm{~g}$ were obtained from the Instituto de Nutrición y Bromatología (CSIC, Madrid, Spain). After an adaptation period of $4 \mathrm{~d}$, they were transferred to the experimental diets (Table 1). The animals were randomly divided into two groups of nine rats each and housed individually in metabolism cells in a temperature-controlled room $\left(21-24^{\circ} \mathrm{C}\right)$ with a $12 \mathrm{~h}$ light $-12 \mathrm{~h}$ dark cycle. They had free access to food and water during the $27 \mathrm{~d}$ experimental period.
The energy densities of the diets were $1793 \mathrm{~kJ} / 100 \mathrm{~g} \mathrm{DM}$ for the unused sunflower-seed oil (US) diet and $1787 \mathrm{~kJ} /$ $100 \mathrm{~g}$ DM for the FS diet.

\section{Frying procedure}

Domestic deep-fat fryers with 3-litre vessels were used for the repeated potato-frying procedure. A total of sixty fryings, at a rate of ten fryings/d, was carried out. The potato: frying oil ratio was kept at $500 \mathrm{~g} / 3$ litres. The potatoes (sliced about $2 \mathrm{~mm}$ thick) absorbed a considerable amount of oil and it was necessary to replenish the fryer baths with oil from the other fryers. The initial number of fryers was seven, but one fryer was eliminated after each ten frying operations, emptying its contents to make up the volume of the other fryers to 3 litres. More details about the frying procedure have been described previously (Sánchez-Muniz et al. 1993).

\section{Fatty acid and tocopherol analyses}

Samples of the oils were saponified with $0.5 \mathrm{M}$-sodium hydroxide and then methylated following the method of Metcalfe et al. (1966). The non-altered and altered fatty acid methyl esters (Me-FA) of the sunflower-seed oils were separated on silica gel columns (E Merck AG, Darmstadt, Germany), using hexane-diethyl ether for the unaltered Me-FA and diethyl ether for the altered Me-FA fraction as previously described (Cuesta et al. 1991). Non-altered Me-FA were analysed by GC, as previously described (Sánchez-Muniz et al. 1998).

Contents of $\alpha$ - and $\gamma$-tocopherol were determined in the oils by HPLC and fluorescence detection (International Union of Pure \& Applied Chemistry, 1992). The results

Table 1. Composition of the semi-synthetic diets containing unused sunflower-seed oil or sunflower-seed oil used repeatedly for frying ( $\mathrm{g} / \mathrm{kg}$ dry matter)

\begin{tabular}{|c|c|c|}
\hline \multirow[b]{2}{*}{ Ingredient } & \multicolumn{2}{|c|}{ Amount in diet } \\
\hline & Unused sunflower-seed oil & Used sunflower-seed oil \\
\hline Protein ${ }^{*}$ & 140 & 140 \\
\hline Fat† & 150 & 150 \\
\hline Wheat starch $\ddagger$ & $327 \cdot 4$ & $327 \cdot 4$ \\
\hline Sucrose & $300 \cdot 0$ & $300 \cdot 0$ \\
\hline Microcrystalline cellulose $\ddagger$ & $50 \cdot 0$ & $50 \cdot 0$ \\
\hline Mineral premix $\S \|$ & $30 \cdot 0$ & $30 \cdot 0$ \\
\hline Vitamin premix§】 & 1.6 & 1.6 \\
\hline Butylated hydroxytoluene§ & 0.5 & 0.5 \\
\hline Butylated hydroxyanisole§ & 0.5 & 0.5 \\
\hline \multicolumn{3}{|c|}{ 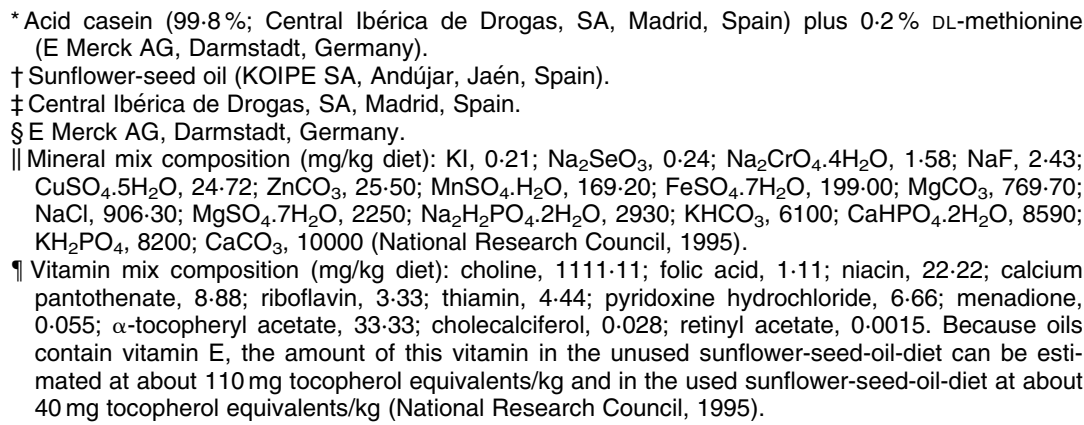 } \\
\hline
\end{tabular}


were expressed as tocopherol equivalents (Food \& Nutrition Board, 1989).

\section{Separation of polar and non-polar materials}

The amount of polar material from the FS and the US was determined using silica gel columns (Romero et al. 1995). The purity of each fraction was then checked by TLC with Merck (Darmstadt, Germany) plates $\left(60_{250}, 0.5 \mathrm{~mm}\right.$ thickness, using a mixture of hexane-diethyl ether-acetic acid (80:20:1, by vol.) as a solvent system).

\section{High-performance size-exclusion chromatography}

The polar material obtained by column chromatography on silica gel was analysed by high-performance size-exclusion chromatography (Dobarganes et al. 1988) to investigate the polar compounds (polymers and dimers of triacylglycerols, oxidised triacylglycerols, diacylglycerols and non-esterified fatty acids). These compounds were determined in a Konic $500 \mathrm{~A}$ chromatograph (Barcelona, Spain) with a $10 \mu$ sample loop. A Hewlett-Packard 1037 A refractive index detector (Palo Alto, CA, USA) and two Polymer Laboratories gel (PL-gel) columns of $0.05 \mu \mathrm{m}$ and $0.01 \mu \mathrm{m}$ (Hewlett-Packard, Madrid, Spain), connected in series, were operated at $40^{\circ} \mathrm{C}$. HPLC-grade tetrahydrofuran (E Merck AG, Darmstadt, Germany) served as the mobile phase, with a flow rate of $1 \mathrm{ml} / \mathrm{min}$ and a sample concentration of $10-15 \mathrm{mg} / \mathrm{ml}$ in tetrahydrofuran. All eluents, as well as samples, were pre-cleaned by passing them through a $2 \mu \mathrm{m}$ filter. The quantity of each compound was calculated as previously described (Sánchez-Muniz et al. 1993).

\section{Lipoprotein isolation}

At the end of the experimental period the rats were anaesthetised with an intraperitoneal injection of sodium pentobarbital $(45 \mathrm{mg} / \mathrm{kg}$ body weight) and killed by extracting blood via carotid puncture. Serum was separated from whole blood within 30 min of collection by centrifugation at $1200 \mathrm{~g}$ for $20 \mathrm{~min}$ at $4^{\circ} \mathrm{C}$. VLDL, LDL and HDL fractions were separated from serum by gradient-density ultracentrifugation for $7 \mathrm{~h}$ at $232000 \mathrm{~g}$ and $8^{\circ} \mathrm{C}$ in a Beckman L8-70M ultracentrifuge, SW-50.1 rotor (Palo Alto, CA, USA) following the method of Terpstra et al. (1981). Lipoproteins were separated by tube slicing at the density range of VLDL $\left(\rho^{20}<1.0063 \mathrm{~g} / \mathrm{ml}\right)$, LDL $\left(1.0063<\rho^{20}<1.057 \mathrm{~g} / \mathrm{ml}\right)$ and HDL $\left(\rho^{20}>1.057 \mathrm{~g} / \mathrm{ml}\right)$.

\section{Serum lipid and lipoprotein lipid analyses}

Total and non-esterified cholesterol, triacylglycerol and phospholipid contents were determined in serum, VLDL, LDL and HDL fractions by standard enzymic analysis (tests 172626, 310328, 701904 and 691844, respectively; Boehringer Mannheim, Darmstadt, Germany). The intraassay $\mathrm{CV}$ was $<5.5 \%$.
Liver, serum, and lipoprotein thiobarbituric acid-reactive substances

Liver samples were homogenised $(50 \mathrm{mg} / \mathrm{ml})$ in $1 \%$ phosphate buffer. TBARS levels in liver and in serum and lipoprotein fractions were measured at $532 \mathrm{~nm}$ on a Philips PU 8620/UV/Vis/NIR spectrophotometer (Cambridge, UK), following the method of Yagi (1993).

\section{Statistical analysis}

Data were analysed using Student's $t$ test. Pearson productmoment correlations were also used. Results were considered significant at $P<0 \cdot 05$.

\section{Results}

Fatty acid composition, polar material, tocopherol, oligomers and thermal oxidised compounds in sunflowerseed oil

Polar material increased $(P<0 \cdot 001)$ in the FS compared with the US. Moreover, compounds related to thermoxidative alteration, such as triacylglycerol polymers, triacylglycerol dimers and oxidised triacylglycerols also increased $(P<0.001)$ in the FS. After sixty fryings, the oil became highly altered. More than $25 \%$ of this oil consisted of polar material and more than $16 \%$ of oligomers (Table 2). Because of the formation of polar material and polymeric triacylglycerols, the level of linoleic and oleic acids decreased significantly $(P<0 \cdot 05)$. The amount of $\alpha$ - and $\gamma$-tocopherols, and thus the tocopherol equivalents, also decreased $(P<0.001)$ after the sixty fryings of potatoes (Table 2). Taking into account the tocopherol equivalents of the diets (vitamin mix plus the oils) and the linoleic acid content of the oils, the tocopherol equivalents:linoleic acid ratio was $1.44 \mathrm{mg} / \mathrm{g}$ in the US diet, and $0.68 \mathrm{mg} / \mathrm{g}$ in the FS diet.

\section{Food intake and body-weight gain}

Food and fat intakes were similar in both groups, but the FS-fed rats consumed significantly lower amounts of oleic and linoleic acids $(P<0.05$ and $P<0.01$, respectively) than those given the US diet. On the other hand, the intake of polar material, polymers, dimers, oligomers, oxidised triacylglycerols and thermoxidised compounds was significantly higher in the FS-fed rats than in the US-fed rats (all $P<0 \cdot 001$ ) (Table 2 ). Weight gain was significantly lower $(P<0 \cdot 05)$ in the FS-fed rats (Table 3$)$.

\section{Faecal excretion}

Faecal excretion tended to decrease in the FS-fed rats (Table 4). However, faeces of the FS-fed rats contained proportionally more fat and moisture than those of the US-fed rats.

\section{Liver size and composition}

FS consumption did not significantly affect liver size, hepatosomatic index or liver fat content. However, livers 
Table 2. Polar material, thermal oxidation and hydrolysis compounds, altered methyl esters and tocopherol content in unused sunflower-seed oil or sunflower-seed oil used repeatedly for frying

(Mean values and standard deviations of three measurements)

\begin{tabular}{|c|c|c|c|c|}
\hline & \multicolumn{2}{|c|}{ Unused oil } & \multicolumn{2}{|c|}{ Used oil } \\
\hline & Mean & SD & Mean & SD \\
\hline Polar material ( $\mathrm{g} / 100 \mathrm{~g}$ oil) & 4.0 & 0.2 & $27 \cdot 7^{\star \star \star}$ & 0.3 \\
\hline Triacylglycerol polymers ( $\mathrm{g} / 100 \mathrm{~g}$ oil) & 0.1 & 0.0 & $5 \cdot 6^{\star \star \star}$ & 0.2 \\
\hline Triacylglycerol dimers ( $\mathrm{g} / 100 \mathrm{~g}$ oil) & 0.5 & 0.0 & $11 \cdot 0^{\star \star \star}$ & 0.2 \\
\hline Non-oxidised triacylglycerols ( $\mathrm{g} / 100 \mathrm{~g}$ oil) & 96.0 & 0.2 & $72 \cdot 3^{* \star *}$ & 0.3 \\
\hline Oxidised triacylglycerols ( $\mathrm{g} / 100 \mathrm{~g}$ oil) & 1.9 & $0 \cdot 1$ & $8 \cdot 9^{\star \star \star}$ & 0.2 \\
\hline Diacylglycerols (g/100 g oil) & 1.0 & 0.1 & $1.7^{\star}$ & $0 \cdot 1$ \\
\hline Monoacylglycerols ( $\mathrm{g} / 100 \mathrm{~g}$ oil) & ND & ND & ND & ND \\
\hline Non-esterified fatty acids ( $\mathrm{g} / 100 \mathrm{~g}$ oil) & 0.5 & 0.0 & 0.5 & $0 \cdot 1$ \\
\hline Non-altered fatty acid methyl esters ( $\mathrm{g} / 100 \mathrm{~g}$ oil) & 98.4 & 0.5 & $84 \cdot 1^{\star \star \star}$ & 0.8 \\
\hline Altered fatty acid methyl esters ( $\mathrm{g} / 100 \mathrm{~g}$ oil) & 1.6 & 0.5 & $15 \cdot 9^{\star \star \star}$ & 0.8 \\
\hline Oleic acid ( $\mathrm{g} / 100 \mathrm{~g}$ oil) & 32.5 & 0.06 & $30.5^{\star \star \star}$ & 0.04 \\
\hline Linoleic acid ( $\mathrm{g} / 100 \mathrm{~g}$ oil) & 55.6 & 0.09 & $44 \cdot 1^{\star \star *}$ & 0.05 \\
\hline Tocopherol equivalents $(\mathrm{g} / \mathrm{kg} \text { oil })^{\star} \ddagger$ & 530 & 11.9 & $49^{\star \star \star}$ & 1.2 \\
\hline$\alpha$-Tocopherols ( $\mathrm{g} / \mathrm{kg}$ oil) & 478 & 10.5 & $44^{\star \star \star}$ & 1.2 \\
\hline$\gamma$-Tocopherols ( $\mathrm{g} / \mathrm{kg}$ oil) & $51 \cdot 2$ & 1.5 & $7 \cdot 2^{\star \star \star}$ & $0 . \overline{4}$ \\
\hline
\end{tabular}

ND, not detected.

Mean value was significantly different from that for the unused oil: ${ }^{\star} P<0.05$, ${ }^{\star \star \star} P<0.01$ (Student's $t$ test).

† For details of procedures, see pp. 258-259.

$\ddagger$ Calculated according to the Food and Nutrition Board (1989).

of the FS-fed rats had a significantly higher TBARS content $(P<0.01)$ than those of the US-fed rats (Table 3$)$. Liver-TBARS concentrations showed a significant linear relationship $(P<0 \cdot 01)$ with the ingestion of all thermoxidised compounds (data not shown).

\section{Serum lipids}

Serum total and non-esterified cholesterol concentrations were significantly higher $(P<0.05)$ in the FS-fed rats
(Table 5). Serum phospholipids were also higher $(P<0.001)$ in the FS-fed rats, whereas serum triacylglycerol concentrations did not vary between the two groups.

\section{Lipoprotein lipids}

Concentrations of VLDL-lipids and VLDL-esterification index were not significantly different in both groups (Table 5). LDL of the FS-fed rats showed higher total and non-esterified cholesterol content $(P<0.01$ and

Table 3. Weight gain, food and fat intake, and food efficiency ratio in rats fed semi-synthetic diets, containing unused sunflower-seed oil or sunflower-seed oil used repeatedly for frying, for $27 \mathrm{~d} \dagger$

(Mean values and standard deviations)

\begin{tabular}{|c|c|c|c|c|}
\hline & \multicolumn{2}{|c|}{$\begin{array}{l}\text { Unused sunflower- } \\
\text { seed-oil diet }(n 9)\end{array}$} & \multicolumn{2}{|c|}{$\begin{array}{l}\text { Used sunflower- } \\
\text { seed-oil diet }(n 9)\end{array}$} \\
\hline & Mean & SD & Mean & SD \\
\hline Initial body weight (g) & $73 \cdot 8$ & $6 \cdot 5$ & $72 \cdot 3$ & 2.9 \\
\hline Final body weight (g) & $180 \cdot 9$ & $14 \cdot 1$ & $144 \cdot 1^{\star \star \star}$ & 14.4 \\
\hline Weight gain (g) & $107 \cdot 1$ & $6 \cdot 3$ & $71 \cdot 8^{\star \star \star}$ & 4.0 \\
\hline Food intake $(\mathrm{g} / \mathrm{d})$ & $12 \cdot 2$ & 0.8 & $11 \cdot 7$ & 0.6 \\
\hline Fat intake $(\mathrm{g} / \mathrm{d})$ & 1.77 & 0.11 & 1.84 & 0.09 \\
\hline Linoleic acid intake (g/d) & 0.95 & 0.03 & $0.78^{\star \star}$ & 0.03 \\
\hline Oleic acid intake (g/d) & 0.61 & 0.03 & $0.54^{\star}$ & 0.03 \\
\hline Polar material intake $(\mathrm{g} / \mathrm{d})$ & 0.08 & 0.01 & $0.50^{\star \star \star}$ & 0.02 \\
\hline Triacylglycerol polymer intake $(\mathrm{g} / \mathrm{d})$ & 0.001 & 0.000 & $0 \cdot 10^{* * *}$ & 0.01 \\
\hline Triacylglycerol dimer intake $(\mathrm{g} / \mathrm{d})$ & 0.01 & 0.00 & $0 \cdot 20^{\star \star \star}$ & 0.01 \\
\hline Triacylglycerol oligomer intake $\neq(\mathrm{g} / \mathrm{d})$ & 0.01 & 0.00 & $0.30^{\star \star \star}$ & 0.01 \\
\hline Oxidised triacylglycerol intake $(\mathrm{g} / \mathrm{d})$ & 0.04 & 0.00 & $0 \cdot 16^{* \star *}$ & 0.01 \\
\hline Thermoxidised compound intake§ $(\mathrm{g} / \mathrm{d})$ & 0.05 & 0.00 & $0.46^{\star \star \star}$ & 0.02 \\
\hline Food efficiency ratio\| & 0.33 & 0.03 & $0.23^{*}$ & 0.05 \\
\hline
\end{tabular}

Mean value was significantly different from that for the unused oil diet: ${ }^{\star} P<0.05$, ${ }^{\star \star} P<0.01$, ${ }^{\star * \star} P<0.001$ (Student's $t$ test).

†For details of diets and procedures, see Tables 1 and 2 and pp. 258-259.

¥Triacylglycerol polymers plus triacylglycerol dimers.

$\S$ Triacylglycerol polymers and dimers plus oxidised triacylglycerols.

\|l Weight gain (g)/food intake (g DM/27 d). 
Table 4. Faecal weight, moisture and fat of rats fed semi-synthetic diets, containing unused sunflower-seed oil or sunflower-seed oil used repeatedly for frying, for $27 \mathrm{~d} \dagger$

(Mean values and standard deviations)

\begin{tabular}{|c|c|c|c|c|}
\hline & \multicolumn{2}{|c|}{$\begin{array}{l}\text { Unused sunflower- } \\
\text { seed-oil diet }(n 9)\end{array}$} & \multicolumn{2}{|c|}{$\begin{array}{l}\text { Used sunflower- } \\
\text { seed-oil diet }(n 9)\end{array}$} \\
\hline & Mean & SD & Mean & $\mathrm{SD}$ \\
\hline \multicolumn{5}{|l|}{ Faeces } \\
\hline Weight (g/d) & $7 \cdot 10$ & 1.41 & 6.75 & $1 \cdot 32$ \\
\hline Moisture (\%) & $5 \cdot 39$ & 0.96 & 5.79 & 0.99 \\
\hline Fat $(\%)$ & 4.19 & 1.02 & 5.05 & 1.56 \\
\hline \multicolumn{5}{|l|}{ Liver } \\
\hline Weight (g) & $5 \cdot 86$ & 1.26 & $5 \cdot 11$ & 0.63 \\
\hline Moisture (\%) & $72 \cdot 3$ & $2 \cdot 25$ & $73 \cdot 6$ & 2.97 \\
\hline Fat $(\%)$ & 3.98 & 0.78 & $4 \cdot 19$ & 0.72 \\
\hline TBARS $(\mathrm{mmol} / \mathrm{g})$ & 0.89 & 0.22 & $1.41^{\star \star}$ & 0.32 \\
\hline Hepatosomatic index (g/100 g body weight) & 3.59 & 0.48 & 3.98 & 0.48 \\
\hline
\end{tabular}

TBARS, thiobarbituric acid-reactive substances.

Mean value was significantly different from that for the unused oil diet: ${ }^{* \star} P<0.01$ (Student's $t$ test)

† For details of diets and procedures, see Tables 1 and 2 and pp. 258-259.

$P<0 \cdot 001$, respectively) but the other lipids and the esterification index were not significantly affected. Total cholesterol and the esterified cholesterol concentrations in HDL were significantly higher $(P<0.05)$ in the FS-fed rats. Similarly, HDL-phospholipid concentrations were higher $(P<0.001)$ in the FS-fed rats. The VLDL-lipid mass tended to be lower whereas the LDL-lipid mass and the HDL-lipid mass tended to be higher in the FS-fed rats.

\section{Serum- and lipoprotein-thiobarbituric acid-reactive substances}

The FS-fed rats had higher TBARS contents in serum and in all lipoproteins than their US-fed counterparts $(P<0.001)$ (Table 5). The HDL fraction was the major TBARS carrier. However, the lipid:TBARS ratio denotes that VLDL was more affected than the other lipoproteins. Serum-TBARS and HDL-TBARS showed a high and significant correlation with liver-TBARS (Figs. 1 and 2), HDL-phospholipids $(r>0.6996 ; P<0.001)$, and HDLcholesterol $(r>0.7148 ; P<0.001)$.

\section{Discussion}

\section{Oil alteration}

Present legislation in many European countries rules that oil should be discarded when its total polar material content is higher than $25 \%$ (Firestone, 1996). However, other European countries indicate that oils with a $10 \%$ oligomer (polymers plus dimers of triacylglycerols) content should be discarded (Firestone, 1996). Nonetheless, in The Netherlands and other countries the limit for oil discarding has been set at $16 \%$ oligomer level (Firestone, 1996). In the present study, the FS surpassed the $16 \%$ oligomer content and the total polar material value of $25 \mathrm{mg} /$ $100 \mathrm{mg}$ oil. Thus, according to current legislation this oil should not be used for frying or other alimentary purposes. However, in the routine study of oil samples from snack bars and restaurants, oils displaying alterations similar to those seen in the present study were found (Dobarganes
\& Márquez-Ruiz, 1998). According to Quiles et al. (2002) tocopherol equivalents decreased after frying, suggesting that vitamin $\mathrm{E}$ is being used to protect the oil against the thermal damage. All these findings prompted us to study the effect of a diet containing this abused oil on food consumption, growth, lipoprotein profile and liver, serum and lipoprotein peroxidation.

\section{Diet consumption}

Food intake is primarily influenced by factors such as taste, smell and texture (Naim et al. 1977). Lipid oxidation has a great influence on flavour, and the oxidation and hydrolysis of fat affect food palatability, spoiling its taste. Nevertheless, the consumption of FS in the present study did not have any significant effect on food intake. It has been reported that the smell and taste of fats that contain more than $25 \%$ polar material was still acceptable, but that fat was considered deteriorated and unacceptable when polar material content exceeded $30 \%$ (Billek, 1985). Oxidised compounds affect fat palatability, whereas polymer compounds related to thermal oxidation do not (Clark \& Serbia, 1991). In a parallel study, our group (SánchezMuniz et al. 1998) found that a diet including oil with less polar material $(18 \mathrm{~g} / 100 \mathrm{~g}$ oil) was well accepted by growing rats. In the present study, the FS had an oligomer content that was thirty times higher than that of the fresh sunflower-seed oil but had an oxidised triacylglycerol content that was only four times higher. These findings may explain, at least in part, the lack of variation in food intake between the two groups.

Final body-weight gain and the food efficiency ratio were lower in the FS-fed rats than in the US-fed rats. Rats fed a high amount of polar material over a 1-year period exhibited growth retardation (Billek, 1985). However, no significant effect on growth was observed when rats were fed used sunflower-seed oil with an oligomer content below 10\% (Sánchez-Muniz et al. 1998). Thus, the $10 \%$ limit suggested for oil discarding seems to be a good initial cut-off point to avoid harmful effects on growing young animals. The presence of lipid peroxides in food 
Table 5. Lipid concentration and different indexes of serum VLDL, LDL and HDL of rats fed semi-synthetic diets, containing unused sunflower-seed oil or sunflower-seed oil used repeatedly in frying, for $27 \mathrm{~d} \dagger$

(Mean values and standard deviations)

\begin{tabular}{|c|c|c|c|c|}
\hline & \multicolumn{2}{|c|}{$\begin{array}{l}\text { Unused } \\
\text { sunflower- } \\
\text { seed-oil-diet } \\
(n 9)\end{array}$} & \multicolumn{2}{|c|}{$\begin{array}{l}\text { Used } \\
\text { sunflower-seed- } \\
\text { oil-diet } \\
(n 9)\end{array}$} \\
\hline & Mean & SD & Mean & SD \\
\hline \multicolumn{5}{|c|}{ Total cholesterol (mmol/l) } \\
\hline Serum & 1.64 & 0.07 & $2 \cdot 04^{*}$ & 0.11 \\
\hline VLDL & 0.03 & 0.01 & 0.03 & 0.02 \\
\hline LDL & $0 \cdot 15$ & 0.06 & $0.22^{\star *}$ & 0.03 \\
\hline HDL & 1.38 & 0.23 & $1 \cdot 69^{\star}$ & 0.23 \\
\hline \multicolumn{5}{|c|}{ Non-esterified cholesterol $(\mathrm{mmol} / \mathrm{l})$} \\
\hline Serum & 0.27 & 0.12 & $0.42^{*}$ & 0.03 \\
\hline VLDL & 0.02 & 0.01 & 0.02 & 0.03 \\
\hline LDL & 0.05 & 0.02 & $0 \cdot 10^{* \star \star}$ & 0.03 \\
\hline HDL & $0 \cdot 19$ & 0.07 & 0.28 & 0.11 \\
\hline \multicolumn{5}{|c|}{ Esterified cholesterol (mmol/l) } \\
\hline Serum & 1.26 & 0.06 & $1 \cdot 63^{\star \star \star}$ & 0.09 \\
\hline VLDL & 0.01 & 0.00 & 0.01 & 0.01 \\
\hline LDL & $0 \cdot 10$ & 0.06 & 0.13 & 0.03 \\
\hline HDL & 1.09 & 0.40 & $1.41^{*}$ & 0.21 \\
\hline \multicolumn{5}{|c|}{ Triacylglycerols (mmol/l) } \\
\hline Serum & 0.34 & $0 \cdot 18$ & 0.30 & 0.06 \\
\hline VLDL & 0.13 & 0.06 & $0 \cdot 11$ & 0.09 \\
\hline LDL & 0.06 & 0.04 & 0.05 & 0.01 \\
\hline HDL & $0 \cdot 13$ & 0.04 & $0 \cdot 13$ & 0.04 \\
\hline \multicolumn{5}{|c|}{ Phospholipids (mmol/l) } \\
\hline Serum & 1.38 & 0.04 & $1.81^{\star \star \star}$ & 0.05 \\
\hline VLDL & 0.04 & 0.01 & 0.02 & 0.01 \\
\hline LDL & 0.04 & 0.02 & 0.06 & 0.02 \\
\hline HDL & 1.23 & 0.18 & $1.64^{\star \star \star}$ & 0.19 \\
\hline \multicolumn{5}{|c|}{ Esterification index $¥ \times 100$} \\
\hline VLDL & $75 \cdot 3$ & 8.5 & $65 \cdot 6$ & 9.9 \\
\hline LDL & $61 \cdot 7$ & $6 \cdot 7$ & $57 \cdot 3$ & 4.7 \\
\hline HDL & $86 \cdot 0$ & 1.8 & $84 \cdot 2$ & $2 \cdot 1$ \\
\hline \multicolumn{5}{|c|}{ Total lipid mass (mmol/l) } \\
\hline VLDL & 0.20 & 0.06 & $0 \cdot 16$ & 0.06 \\
\hline LDL & 0.25 & 0.12 & 0.34 & 0.20 \\
\hline HDL & $2 \cdot 64$ & 0.60 & 3.46 & 0.67 \\
\hline \multicolumn{5}{|c|}{ TBARS (mmol/l) } \\
\hline Serum & 1.27 & 0.14 & $2 \cdot 22^{\star * *}$ & 0.48 \\
\hline VLDL & 0.20 & 0.07 & $0.35^{\star \star \star}$ & 0.10 \\
\hline LDL & $0 \cdot 16$ & 0.05 & $0.34^{* * *}$ & 0.17 \\
\hline HDL & 0.85 & 0.12 & $1.49^{\star \star \star}$ & 0.41 \\
\hline \multicolumn{5}{|c|}{ Lipid:TBARS ratio } \\
\hline VLDL & 1.00 & 0.12 & $0.46^{\star \star \star}$ & 0.09 \\
\hline LDL & 1.56 & 0.63 & 1.00 & 0.12 \\
\hline HDL & $3 \cdot 10$ & 0.66 & $2 \cdot 32^{*}$ & 0.29 \\
\hline
\end{tabular}

TBARS, thiobarbituric acid-reactive substances.

Mean value was significantly different from that for the unused oil diet: ${ }^{\star} P<0.05,{ }^{* \star} P<0.01,{ }^{* \star *} P<0.001$.

†For details of diets and procedures, see Tables 1 and 2 and pp. 258-259. $\ddagger$ Esterified cholesterol/total cholesterol.

is undesirable because nutritional value decreases with the destruction of unsaturated fatty acids and other essential food constituents that possess an unsaturated lipid structure (Kahl \& Hildebrandt, 1986). This effect was also found in the present study, as the amount of linoleic acid ingested by the FS-fed rats was significantly lower than that of the control group, because a considerable amount of linoleic acid has been oxidised or converted into altered compounds.

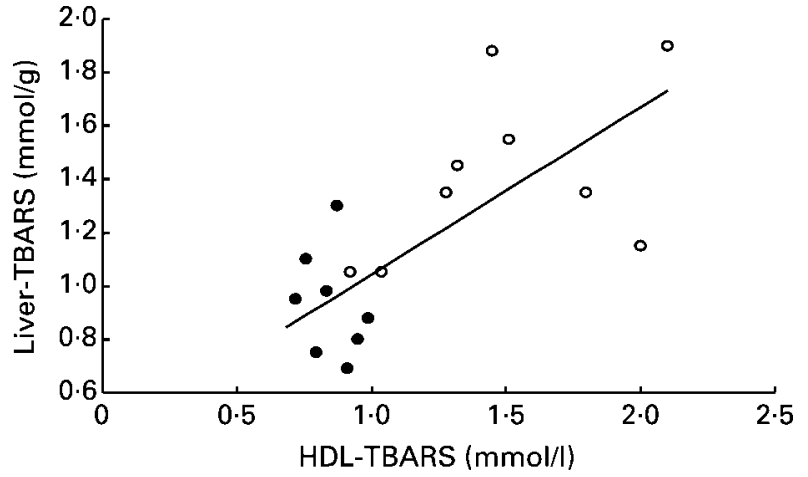

Fig. 1. Relationship between HDL-thiobarbituric acid reactive substances (TBARS) and liver-TBARS in rats fed semi-synthetic diets containing unused sunflower-seed oil $(\bullet)$ or sunflower-seed oil used repeatedly for frying $(\circ)$. The relationship is described by $y=0.6262 x+0.4174$, where $y$ is liver-TBARS and $x$ is HDLTBARS $(r 0.7217 ; P<0.001)$.

\section{Liver composition and peroxidation}

In agreement with Izaki et al. (1984), the present results on liver-TBARS appeared highly influenced by the intake of thermoxidised compounds. The peroxide content of chylomicrons in rats is determined by the lipid peroxide content of the diet (Stapräns et al. 1993a). Remnants of these oxidised chylomicrons are recognised and cleared by the liver. Following $6 \mathrm{~h}$ of intraduodenal infusion of peroxidised oil emulsion the rat liver displays a considerable level of lipid hydroperoxides (TBARS) (Ty et al. 1992). Thus, it should be accepted that the higher TBARS level in the liver of the rats fed the FS diet is a consequence of the higher alteration of the oil. The thermoxidised compounds that most affected liver-TBARS levels were polymers, because the regression line describing the correlation between these two parameters had the steepest slope. In turn, liver-TBARS values seemed to significantly affect the levels of VLDL-TBARS and those of the other lipoproteins, suggesting that a substantial percentage of the oxidised lipids delivered to the liver were repackaged and secreted into VLDL.

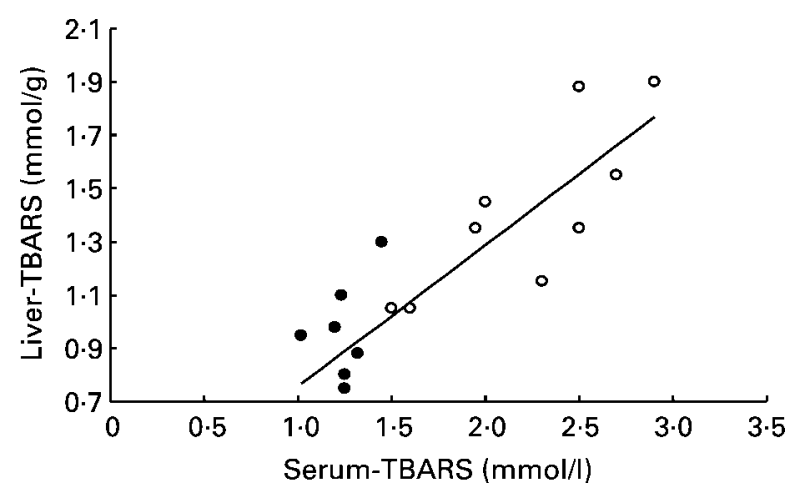

Fig. 2. Relationship between serum-thiobarbituric acid reactive substances (TBARS) and liver-TBARS in rats fed semi-synthetic diets containing unused sunflower-seed oil $(\bullet)$ or sunflower-seed oil used repeatedly for frying (०). The relationship is described by $y=0.5335 x+0.2222$, where $y$ is liver-TBARS and $x$ is serumTBARS ( $r 0.8393 ; P<0.001)$. 


\section{Effects on serum lipids and lipoproteins}

PUFA, primarily linoleic acid, are known to be hypocholesterolaemic (Grundy \& Denke, 1990; Mensink \& Katan, 1992). A high intake of linoleic acid has been shown to decrease both LDL- and HDL-cholesterol levels (Grundy \& Denke, 1990; Mensink \& Katan, 1992). Thus, one explanation for the rise of serum total cholesterol and LDL- and HDL-cholesterol levels following the ingestion of the FS diet may be the lower intake of linoleic acid by the rats of this group. However, although diets with a high linoleic acid content reduce serum LDL-cholesterol, linoleic acid appears to be a major source of lipid oxidation in atherogenesis (Esterbauer et al. 1992). Some time ago, our research group (Cuesta et al. 1987) reported higher levels of total and esterified cholesterol in FS-fed rats than in their US-fed counterparts. In that study the concentration of linoleic acid in the olive oil decreased from 7.89 to $3.76 \%$ after the oil was used thirty times to fry potatoes. Our group further found that rats fed fried sunflower-seed oil with $18 \%$ polar material exhibited higher total serum HDL- and LDL-cholesterol levels than their respective controls (Sánchez-Muniz et al. 1998).

The diets in the present study contained the antioxidant vitamin $\mathrm{E}$, butylated hydroxytoluene and butylated hydroxyanisole but these did not appear to be completely effective in blocking the peroxidative stress in the FS-fed rats. In fact, serum-TBARS appeared to be increased in the FS-fed rats. Several authors have found that vitamin E decreases during the frying of oil (Márquez-Ruiz et al. 1999; Andrikopoulos et al. 2002). Compared with the control diet, the diet containing the altered oil had a lower amount of tocopherol equivalents. However, the amount of tocopherol equivalents in both diets seemed enough and adequate to prevent further linoleic acid oxidation, because an $\alpha$-tocopherol:linoleic acid ratio of about $0.6 \mathrm{mg} / \mathrm{g}$ has been suggested as adequate to avoid oxidative damage (Arbolés et al. 2003).

We also evaluated the effects of the FS and US diets on serum lipoprotein levels and composition. The consumption of FS had non-significant effects on the composition of the VLDL. However, the LDL and HDL fraction of the FS-fed rats was enriched in total and non-esterified cholesterol, possibly because these rats consumed less linoleic acid, known to exert a hypocholesterolaemic effect on the LDL and HDL fractions (Grundy \& Denke, 1990; Mensink \& Katan, 1992).

Lecithin cholesterol acyltransferase, an enzyme that acts on HDL and whose substrate is non-esterified cholesterol, is a key component of reverse cholesterol transport (Steinberg, 1987). In murine lipid metabolism, HDL accepts non-esterified cholesterol from the peripheral tissues and the nonesterified cholesterol is converted to the ester form by the action of lecithin cholesterol acyltransferase. Subsequently, the cholesteryl esters are delivered to the liver. In the rat, a great hepatic uptake of cholesteryl ester from HDL has been observed (Glass et al. 1983; Steinberg, 1987). Thus, higher levels of HDL may enhance reverse cholesterol transport from the peripheral tissues to the liver.

Furthermore, HDL is known to carry a large amount of cholesteryl ester hydroperoxides via reverse transport
(Mackness \& Durrington, 1995). In addition, HDL limit the oxidative modifications of LDL (Mackness \& Durrington, 1995), decreasing the formation of lipid peroxides and related molecules. Thus, increased HDL-cholesterol and HDL-phospholipid levels in FS-fed rats may be a protective mechanism against the higher intake of thermoxidised compounds and a mechanism to avoid oxidative change in other lipoproteins such as LDL.

In addition, HDL particles are associated with paraoxonase 1 activity. This enzyme exerts an important role in protecting LDL and HDL from oxidation in man and other animals (Canales \& Sánchez-Muniz, 2003) and is very active in rats (Kudchodkar et al. 2000). Of all serum lipids, serum phospholipids and very-high-density lipoprotein-phospholipids were strongly related to paraoxonase 1 (Kudchodkar et al. 2000). Plasma paraoxonase 1 mass depends on the number of HDL particles (Nevin et al. 1996). In the present paper, the HDL lipid mass tended to increase following the consumption of the FS diet. Moreover, HDL-phospholipids contributed $95.3 \%$ of total serum phospholipids in the FS-fed rats while this contribution was $93.9 \%$ in their US-fed counterparts. Thus, it can be hypothesised that the increase in HDL and HDLphospholipid levels may be a mechanism to keep as low as possible the oxidative alteration in serum and tissues induced by the consumption of diets containing oxidised lipids. The results also suggest the need for future studies on the long-term effects of modified lipid intake on lipoprotein profile and atheroma development. Meanwhile, the consumption of altered oils should be markedly restricted because of the deleterious implications for health of the toxic compounds they contain (LópezVarela et al. 1995).

\section{Conclusions}

The present study documents that dietary polymerised and thermoxidised sunflower-seed oil increases the levels of cholesterol and phospholipid in plasma and HDL and the levels of TBARS in liver and plasma lipoproteins. These insights have human dietary implications since there is evidence that diets of developed countries contain substantial quantities of PUFA that have been subjected to various degrees of processing and heat treatment, particularly deep-fat frying, which is know to cause lipid oxidation.

\section{Acknowledgements}

The authors are indebted to Dr Carmen Dobarganes, Dr M. Carmen Pérez-Camino and Dr Carmen Cuesta for their valuable contribution. The study was supported by a grant of the Spanish Comision Interministerial de Ciencia y Tecnología (CICYT) (project no. ALI-92-0289-C02-01).

\section{References}

Andrikopoulos NK, Dedoussis GV, Falirea A, Kalogeropoulos N \& Hatzinikola HS (2002) Deterioration of natural antioxidant species of vegetable edible oils during the domestic deep-frying and pan-frying of potatoes. Int J Food Sci Nutr 53, 351-363. 
Arbolés G, Carbajal A, Gonzalvo B, et al. (2003) Nutrición y recomendaciones dietéticas para personas mayores. (Nutrition and dietetic recommendations for elderly people). Grupo de trabajo 'Salud pública' de la Sociedad Española de Nutrición (SEN). Nutr Hosp 18, 113-141.

Bastida S \& Sánchez-Muniz FJ (2002) Polar content vs. TAG oligomer content in the frying-life assessment of monounsaturated and polyunsaturated oils used in deep frying. $\mathrm{J} \mathrm{Am} \mathrm{Oil}$ Chem Soc 79, 447-451.

Billek G (1985) Heated fats in the diet. In The Role of Fats in Human Nutrition, pp. 163-171 [FB Padley and J Podmore, editors, in collaboration with JP Brun, R Burt and BW Nicols]. Chichester: Ellis Horwood Ltd.

Canales A \& Sánchez-Muniz FJ (2003) Paraoxonase, something more than an enzyme? (in Spanish). Med Clin (Barc) 12, $537-548$.

Clark WL \& Serbia GW (1991) Safety aspects of frying fat oils. Food Technol 45, 84-89.

Cuesta C, Sánchez-Muniz FJ \& Hernández I (1991) Evaluation of non polar methyl esters by column and gas chromatography for the assessment of used frying olive oils. J Am Oil Chem Soc 68, 443-445.

Cuesta C, Sánchez-Muniz FJ, Rodríguez A \& Varela G (1987) Physico-chemical changes in olive oil used in repeated frying and its impact on blood lipoproteins in rats (in Spanish). Rev Esp Fisiol 43, 51-56.

Dobarganes MC \& Márquez-Ruiz G (1998) Regulation of used frying fats and validity of quick tests for discarding the fats. Grasas y Aceites 49, 331-335.

Dobarganes MC, Pérez-Camino MC \& Márquez-Ruiz G (1988) High performance size exclusion chromatography of polar compounds in heated and non-heated fats. Fat Sci Technol 90, 308-311.

Esterbauer H, Gebicki J, Puhl H \& Jürgens G (1992) The role of lipid peroxidation and antioxidants in oxidative modification of LDL. Free Radic Biol Med 13, 341-390.

Firestone D (1996) Regulation of frying fat and oil. In Deep Frying Chemistry, Nutrition and Practical Applications, pp. 323-334 [EG Perkins and MD Erickson, editors]. Champaign, IL: AOACS Press.

Food and Nutrition Board (1989) Recommended Dietary Allowances, 10th ed., Washington, DC: National Academic Press.

Frankel EN, Smith LM, Hamblin CL, Creveling RK \& Cliford AJ (1984) Occurrence of cyclic fatty acid monomers in frying oils used for fast foods. J Am Oil Chem Soc 61, 87-90.

Glass C, Pittman RC, Weinsteim DB \& Steinberg D (1983) Dissociation of tissue uptake of cholesterol ester from that of apoprotein A-I of rat plasma high density lipoprotein: selective delivery of cholesterol ester to liver, adrenal and gonad. Proc Natl Acad Sci USA 80, 5435-5439.

Grundy SM \& Denke MA (1990) Dietary influences on serum lipids and lipoproteins. J Lipid Res 31, 1149-1172.

International Union of Pure and Applied Chemistry (1992) IUPAC method 2.432. In Standard Methods for the Analysis of Oils, Fats and Derivatives, 1st supplement to 7th ed., pp. 2.432/1-2.432/7 [A Dieffenbacher and WD Pocklington, editors]. Oxford: Pergamon Press.

Izaki Y, Yoshikawa S \& Uchiyama M (1984) Effect of ingestion of thermally oxidized frying oil on peroxidative criteria in rats. Lipids 19, 324-331.

Kahl R \& Hildebrandt AG (1986) Methodology for studying antioxidant activity and mechanisms of action of antioxidants. Chem Toxicol 24, 1007-1014.

Kudchodkar BJ, Lacko AG, Dory L \& Fungwe TV (2000) Dietary fats modulate serum paraoxonase 1 activity in rats. $J$ Nutr $\mathbf{1 3 0}$, 2427-2433.

López-Varela S, Sánchez-Muniz FJ \& Cuesta C (1995) Decreased food efficiency ratio, growth retardation and changes in liver composition in rats consuming thermoxidized and polymerized sunflower oil used for frying. Food Chem Toxicol 33, 181-189.

Mackness MI \& Durrington PN (1995) HDL, its enzymes and its potential to influence lipid peroxidation. Atherosclerosis 115, $243-249$.

Márquez-Ruiz G, Martín Polvillo M, Jorge N, Ruiz Méndez MV \& Dobarganes MC (1999) Influence of used frying oil quality and natural tocopherol content on oxidative stability of fried potatoes. J Am Oil Chem Soc 76, 421-425.

Mensink RP \& Katan MB (1992) Effect of dietary fatty acids on serum lipids and lipoproteins. A meta-analysis of 27 trials. Arterioscler Thromb 12, 911-919.

Metcalfe LV, Schmitz AA \& Pelka JR (1966) Rapid preparation of fatty acid esters from lipids for gas chromatographic analysis. Anal Chem 38, 514-515.

Naim M, Morley R, Kare H \& Ingle ED (1977) Sensory factors which affect the acceptance of raw and heated defatted soybeans by rats. J Nutr 109, 1653-1658.

National Research Council (1985) Guide for the Care and Use of Laboratory Animals. publication no. 86-23 (rev.). Washington, DC: NHI.

National Research Council (1995) Nutrient Requirements of Laboratory Animals, 4th revised ed. Washington, DC: National Academic Press.

Nevin DN, Zambon A, Furlong CE, Richter RJ, Humbert R, Hokanson JE \& Brunzelli JD (1996) Paraoxonase genotypes, lipoprotein lipase activity, and HDL. Arterioscler Thromb Vasc Biol 16, 1243-1249.

Quiles JQ, Ramirez-Tortosa MC, Gómez JQA, Huertas JR \& Mataix J (2002) Role of vitamin E and phenolic compounds in the antioxidant capacity, measured by ESR, of virgin olive, olive and sunflower oils after frying. Food Chem 76, 461-468.

Romero A, Sánchez-Muniz FJ \& Cuesta C (2000) Deep fat frying of frozen foods in sunflower oil. Fatty acid composition in fryer oil and frozen prefried potatoes. J Sci Food Agric 80, 2135-2141.

Romero A, Sánchez-Muniz FJ, Tulasne C \& Cuesta C (1995) High-performance size-exclusion chromatographic studies on a high-oleic acid sunflower oil during potato frying. $J$ Am Oil Chem Soc 72, 1513-1517.

Sánchez-Muniz FJ, Arroyo R, Sánchez-Montero JM \& Cuesta C (2000) In vitro digestibility study of thermal oxidized palm oleins. Food Sci Tech Int 6, 449-456.

Sánchez-Muniz FJ, Bastida S \& González-Muñoz MJ (1999) Column and high-performance size exclusion chromatography applications to the in vivo digestibility study of a thermoxidised and polymerised olive oil. Lipids $\mathbf{3 4}$, $1187-1192$.

Sánchez-Muniz FJ \& Cuesta C (1998) Lipid metabolism in experimental animals. Grasas y Aceites 49, 340-347.

Sánchez-Muniz FJ, Cuesta C \& Garrido-Polonio MC (1993) Sunflower oil used for frying. Combination of column, gas and high-performance size exclusion chromatography for its evaluation. J Am Oil Chem Soc 70, 235-240.

Sánchez-Muniz FJ, Lopez-Varela S, Garrido-Polonio MC \& Cuesta C (1998) Dietary effects on growth, liver peroxides, and serum and lipoprotein lipids in rats fed a thermoxidised and polymerised sunflower oil. J Sci Food Agric 76, 364-372.

Stapräns I, Pan XM, Miller M \& Rapp JH (1993a) Effect of dietary lipid peroxide on metabolism of serum chylomicrons in rats. Am J Physiol 264, G561-G568.

Stapräns I, Rapp JH, Pan XM \& Feingold KR (1993b) The effect of oxidized lipids in the diet on serum lipoprotein peroxides in control and diabetic rats. $J$ Clin Invest 92, 638-643.

Steinberg D (1987) Transport of cholesterol and cholesterol ester 
by HDL. In Drugs Affecting Lipid Metabolism, pp. 42-47

[R Paoletti, D Kritchevsky and WL Holmes, editors]. Berlin: Springer-Verlag.

Terpstra AHM, Woodward CRH \& Sánchez-Muniz FJ (1981) Improved techniques for the separation of serum lipoproteins by density gradient ultracentrifugation. Visualization on prestaining and rapid separation of serum lipoproteins from small volumes of serum. Anal Biochem 111, 149-157.
Ty AW, Williams MW \& Gray ML (1992) Absorption and lymphatic transport of peroxidized lipids by rat small intestine in vivo: role of mucosal GSH. Am J Physiol 262, G99-G101.

Yagi K (1993) Lipid peroxides, free radicals, and diseases. In Active Oxygen, Lipid Peroxides, and Antioxidants, pp. 39-56. Boca Raton, FL: CRC Press and Tokyo: Japan Science Society Press. 